\title{
Ribosomal RNA Genes in Kluyveromyces marxianus
}

\author{
By M. OJHA \\ Laboratoire de Microbiologie générale, Département de Biologie végétale, \\ Université de Genève, CH-1211 Genève 4, Switzerland
}

(Received 9 May 1979; revised 28 August 1979)

\begin{abstract}
DNA from the yeast Kluyveromyces marxianus was studied for its heterogeneity and the multiplicity of rRNA cistrons. These cistrons banded at a slightly different density from the bulk DNA in preparative $\mathrm{CsCl}$ or $\mathrm{Hg}^{2+}-\mathrm{Cs}_{2} \mathrm{SO}_{4}$ equilibrium density gradients. The reassociation kinetics of the bulk DNA showed that the repetitive fraction represented a small amount of the total cellular DNA (10\%) and that the single copy fraction had a complexity of $6.3 \times 10^{9}$ daltons. Approximately $2.2 \%$ of the DNA hybridized to ${ }^{3} \mathrm{H}$ labelled rRNA at saturation. On the basis of the above genome size, the multiplicity of the rRNA cistrons was calculated to be about 70 per haploid nucleus.
\end{abstract}

\section{INTRODUCTION}

Information concerning the physical properties, multiplicity and organization of ribosomal RNA cistrons in yeasts has been mainly derived from studies with Saccharomyces cerevisiae (Cryer et al., 1973; Kaback et al., 1973). These investigations have revealed that there are approximately 100 to 140 cistrons per haploid genome (the haploid genome size is approximately $5 \times 10^{9}$ to $8 \times 10^{9}$ daltons), coding for $25,18,5.8$ and $5 \mathrm{~S}$ rRNA each. The 140 cistrons are not contiguous but 10 to 32 cistrons are grouped in clusters on more than one chromosome. These conclusions are based on the appearance of rDNA peaks on equilibrium density gradient centrifugation of DNA fragmented to defined molecular weight (Cramer et al., 1972). A Saccharomyces cerevisiae strain monosomic (2n-1) for chromosome I contains about $30 \%$ fewer genes coding for rRNA than the related diploid strain, indicating that about $70 \%$ of the rRNA cistrons are located on chromosome I (Øyen, 1973; Finkelstein et al., 1972; Kaback et al., 1973). In experiments with intact chromosomal DNA sedimented in sucrose gradients the rDNA was shown to be associated with two size classes of DNA molecules, one of which was linked to chromosome I (Finkelstein et al., 1972).

Kluyveromyces is so closely related to Saccharomyces that Campbell (1972) has suggested the rejection of Kluyveromyces as a genus. However, studies of the nucleotide sequence homology (Bicknell \& Douglas, 1970), genetic analysis (Tingle et al., 1968) and the difference in the chromosome number ( $K$. lactis has a haploid chromosome number of 9 compared to 15 for $S$. cerevisiae; Galeotti \& Williams, 1978) justify the retention of Kluyveromyces as a separate genus. In view of these obvious similarities and differences we thought an investigation of the organization of rRNA cistrons in Kluyveromyces worthwhile. In this paper we report our results on the characterization of rRNA cistrons in $K$. marxianus. 


\section{METHODS}

Organism, growth and DNA extraction. Kluyveromyces marxianus strain no. 712 CBS was maintained on malt agar slants at $25^{\circ} \mathrm{C}$. Yeast cells were scraped from malt agar slants ( 4 to $5 \mathrm{~d}$-old), washed with distilled water by centrifugation, and inoculated in 11 growth medium to give a density of about $1 \times 10^{9} \mathrm{cells}^{\mathrm{m}} \mathrm{ml}^{-1}$. The growth medium, YPG (containing, per litre, $10 \mathrm{~g}$ yeast extract, $20 \mathrm{~g}$ peptone and $40 \mathrm{~g}$ glucose), was prepared in a 21 Erlenmeyer flask and the culture was grown at $25^{\circ} \mathrm{C}$ with forced aeration. After $48 \mathrm{~h}$, the cells were harvested by centrifugation, washed with distilled water and frozen in liquid nitrogen. The frozen cell clumps were broken and ground to fine powder in liquid nitrogen with a Braun homogenizer. The broken cell powder was suspended in a lysing buffer $(8 \mathrm{M}$-urea $/ 0 \cdot 24 \mathrm{M}$-sodium phosphate buffer $\mathrm{pH} 6.8 /$ $1 \%(w / v)$ sodium dodecyl sulphate/10 mM-EDTA/1 M-sodium perchlorate) and deproteinized twice with chloroform/isoamyl alcohol $(24: 1, \mathrm{v} / \mathrm{v})$. The DNA from the deproteinized supernatant was extracted on hydroxyapatite and further purified as described by Dutta \& Ojha (1972).

Analytical equilibrium density gradient centrifugation. DNA $\left(5 \mu \mathrm{g} \mathrm{ml}^{-1}\right)$ was prepared in either $\mathrm{CsCl}$ or $\mathrm{Cs}_{2} \mathrm{SO}_{4}$ solution, the latter containing $\mathrm{HgCl}_{2}$ or $\mathrm{AgNO}_{3}$ at heavy metal ion to DNAp ratios of $0 \cdot 1$ and $0 \cdot 3$, respectively, as described elsewhere (Ojha \& Turian, 1977). The samples were centrifuged in an MSE analytical ultracentrifuge at $140000 \mathrm{~g}$ for $24 \mathrm{~h}$ at $25^{\circ} \mathrm{C}$. Ultraviolet photographs were traced using a Vernon photometric integrator recorder.

Preparative ultracentrifugation. $\mathrm{CsCl}, \mathrm{Hg}^{2+}$ and $\mathrm{Ag}^{+}-\mathrm{Cs}_{2} \mathrm{SO}_{4}$ density gradient equilibrium centrifugation was done as described earlier (Ojha \& Turian, 1977). CsCl-actinomycin D gradient centrifugation was done according to Peacock et al. (1973). The actinomycin D complexed to DNA fractions was removed by extracting the DNA/CsCl/actinomycin D solution with propan-2-ol. This procedure was repeated twice. The $\mathrm{Hg}^{2+}$ or $\mathrm{Ag}^{+}$ions complexed to DNA fractions were removed with $0.001 \mathrm{M}$-EDTA as described elsewhere (Ojha \& Turian, 1977).

Individual fractions were denatured, neutralized, fixed on Millipore filters and hybridized with ${ }^{3} \mathrm{H}-$ labelled rRNA from an aquatic fungus, Allomyces arbuscula (Ojha \& Turian, 1977).

Thermal denaturation. The procedure followed has been described previously (Ojha, 1978). The denaturation profile was analysed by the differential melting curve and the probability plot method of Knittel et al. (1968).

Reassociation kinetics. The fragmentation of the DNA samples, evaluation of the fragment length, denaturation and the procedure of reassociation have been described elsehwere (Ojha et al., 1977).

A minimum of 1 unit of absorbance of the fragmented DNA was sealed in the reaction vials and incubated at $60{ }^{\circ} \mathrm{C}$. After incubation to the desired $C_{0} t$ value $\left(C_{0} t\right.$ is the concentration of nucleotide in $\mathrm{mol} \mathrm{s}^{-1} \mathrm{l}^{-1}$; Britten \& Kohne, 1968), further reassociation was terminated by quickly plunging the vials into ice. The reassociated DNA was differentiated on hydroxyapatite columns as described elsewhere (Dutta \& Ojha, 1972).

Isolation of ${ }^{3} \mathrm{H}$-labelled $r R N A$ from $K$. marxianus. YPG medium $(500 \mathrm{ml})$ containing $500 \mu \mathrm{Ci}(18.5 \mathrm{MBq})$ $\left[{ }^{3} \mathrm{H}\right.$ ] uridine was inoculated with $7 \mathrm{~d}$-old cells grown on grape juice slants and incubated with forced aeration at $25^{\circ} \mathrm{C}$. After $24 \mathrm{~h}$ growth, 100 times the quantity of unlabelled uridine was added and the culture was allowed to grow for another $5 \mathrm{~h}$. The ribosomes and rRNA were isolated according to Rubin (1975). The rRNA subunits $(25+18 \mathrm{~S})$ were purified by polyacrylamide-agarose (acrylamide, $2 \cdot 4 \%, \mathrm{w} / \mathrm{v}$; agarose, $0.5 \%, \mathrm{w} / \mathrm{v}$ ) electrophoresis and rRNA species were recovered as described by Rubin (1975).

\section{RESULTS}

\section{Satellite DNAs}

The presence of satellite DNAs was investigated by analytical equilibrium centrifugation in $\mathrm{CsCl}, \mathrm{Hg}^{2+}-$ or $\mathrm{Ag}^{+}-\mathrm{Cs}_{2} \mathrm{SO}_{4}$ and by analysis of the melting curve by the differential or probability plot method of Knittel et al. (1968). The equilibrium density gradient centrifugations did not reveal the presence of distinct satellites. However, the probability plot of the denaturation data showed the presence of two populations of molecules differing in their $\mathrm{G}+\mathrm{C}$ values. The major and minor components had 43 and $23 \mathrm{~mol} \% \mathrm{G}+\mathrm{C}$, respectively.

\section{Frequency of ribosomal RNA genes}

Saturation hybridization. The number of ribosomal RNA gene copies in the $K$. marxianus genome was estimated by hybridizing denatured DNA immobilized on nitrocellulose filters 

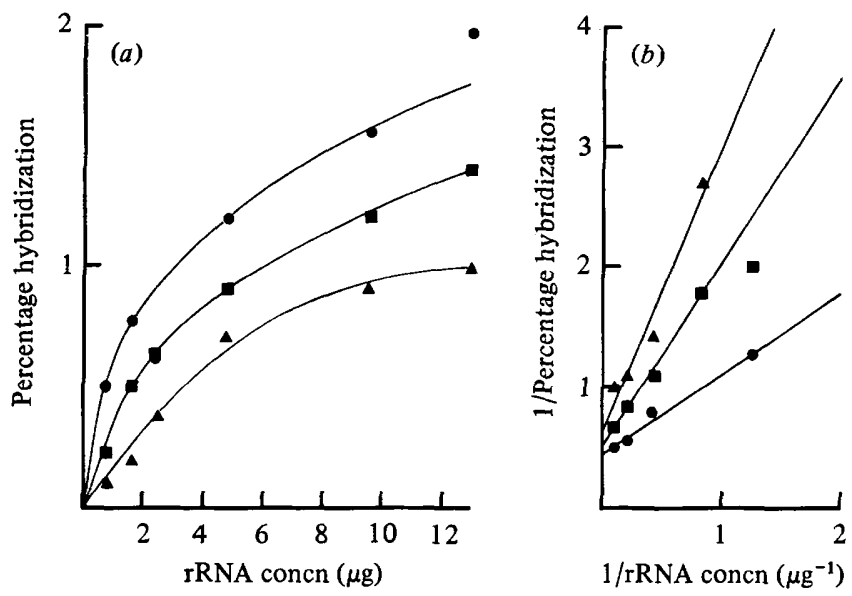

Fig. 1. Saturation hybridization of $K$. marxianus, $S$. cerevisiae and $N$. crassa DNA with ${ }^{3} \mathrm{H}-$ labelled rRNA $(25+18 S)$ from $K$. marxianus. (a) Respective DNAs were fixed on nitrocellulose filters and hybridized with increasing concentrations of rRNA (sp. act. 7000 c.p.m. $\mu \mathrm{g}^{-1}$ ) under the conditions described in Methods. (b) Double reciprocal plots of the saturation data. $K$. marxianus; $\square, S$. cerevisiae; $\Delta, N$. crassa.

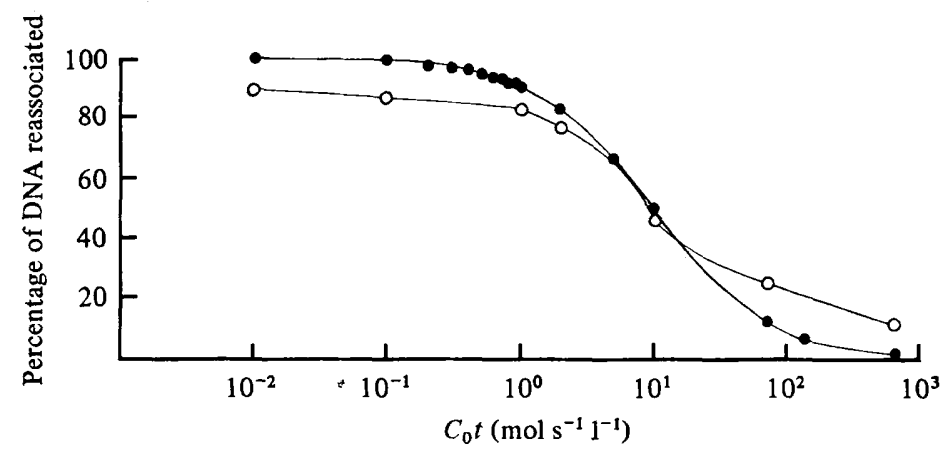

Fig. 2. Reassociation kinetics of $K$. marxianus DNA. DNA was sheared (average fragment length 1000 base pairs), denatured and reassociated as indicated in Methods. DNA concentration, phosphate buffer molarities and temperatures of incubation were as follows: from $C_{0} t 10^{-3}$ to $10^{\circ}-40 \mu \mathrm{g} \mathrm{ml}^{-1}, 0.12 \mathrm{M}$ and $60^{\circ} \mathrm{C}$; from $C_{0} t 10^{\circ}$ to $10^{2}-850 \mu \mathrm{g} \mathrm{ml}^{-1}, 0.14 \mathrm{M}$ and $60^{\circ} \mathrm{C}$; from $C_{0} t 10^{2}$ to $10^{3}-1150 \mu \mathrm{g} \mathrm{ml}^{-1}, 0.48 \mathrm{M}$ and $66^{\circ} \mathrm{C}$. The reassociated fractions were separated from the unreassociated DNA by hydroxyapatite chromatography as described by Dutta \& Ojha (1972). $\mathrm{O}$, Experimental results; , theoretical curve of possible single copy sequences.

with increasing concentrations of combined ${ }^{3} \mathrm{H}$-labelled $(25+18 \mathrm{~S})$ homologous rRNA (Fig. 1). The plateau value obtained revealed that $1.6 \%$ of the DNA was complementary to rRNA at saturation. The saturation value of $2.2 \%$ was obtained by the double reciprocal transformation (Bishop, 1972) of the above data and represents the percentage hybridization at infinite concentration of the rRNA. As a control, heterologous hybridization was done with $S$. cerevisiae and Neurospora crassa DNA; the saturation values obtained were 2.4 and $1 \%$, respectively (Fig. 1 ).

Genome size. The genome size was determined from the rate of reassociation of the total cellular DNA. From the reassociation kinetics of total cellular DNA sheared to an average length of 1000 base pairs (Fig. 2), the following results were obtained. (1) Repetitive sequences represented a very small amount of the total DNA; approximately $10 \%$ of the DNA reassociated faster than expected from single copy sequences. (2) The slowly re- 


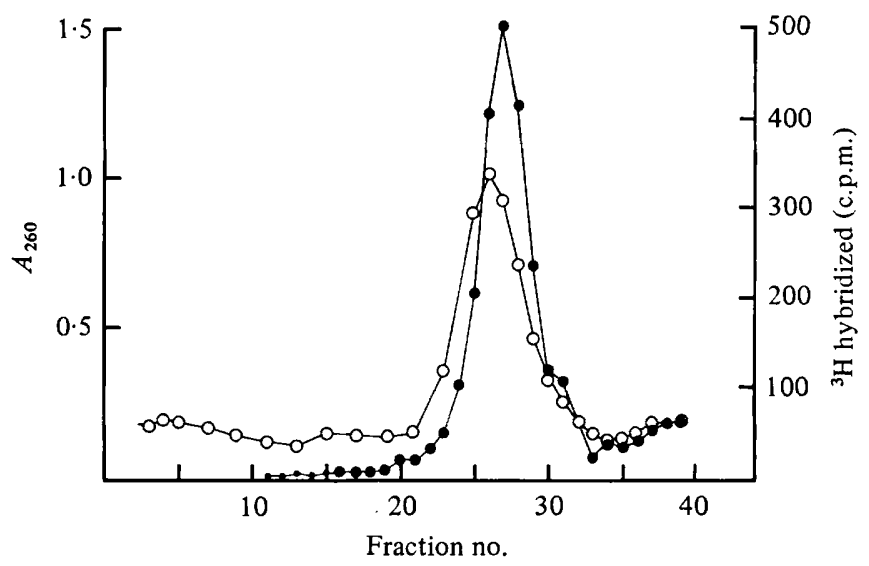

Fig. 3. Banding profile of rRNA cistrons of $K$. marxianus in the preparative neutral $\mathrm{CsCl}$ equilibrium density gradient. Total cellular DNA $(100 \mu \mathrm{g})$ was centrifuged to equilibrium at $95000 \mathrm{~g}$ for $60 \mathrm{~h}$ in an MSE $10 \times 10$ rotor. Individual fractions were collected and their $A_{260}$ values were recorded. The DNA in each fraction was then denatured, neutralized, immobilized on nitrocellulose filters and hybridized with ${ }^{3} \mathrm{H}$-labelled rRNA from $A$. arbuscula (sp. act. 8600 c.p.m. $\mu \mathrm{g}^{-1}$ ) for $4 \mathrm{~h}$ in $6 \times \mathrm{SSC}$ buffer at $60{ }^{\circ} \mathrm{C}$ as indicated in Methods. $\bigcirc, A_{260} ; O,{ }^{3} \mathrm{H}$ hybridized.

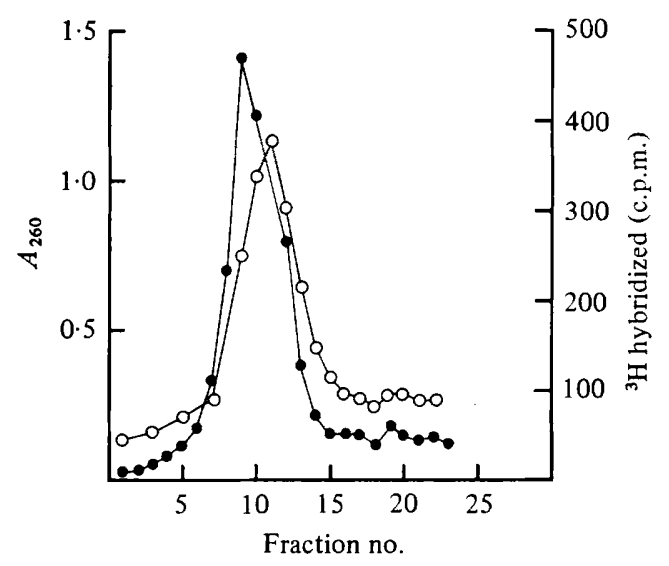

Fig. 4. Banding profile of rRNA cistrons of $K$. marxianus in the preparative $\mathrm{Hg}^{2+}-\mathrm{Cs}_{2} \mathrm{SO}_{4}$ equilibrium density gradient. The samples were prepared in $0 \cdot 1 \mathrm{M}$-borate buffer $\mathrm{pH} 9 \cdot 2$. The $\mathrm{Hg}^{2}:$ to DNAp ratio was $0 \cdot 1$. The conditions of centrifugation, fractionation and hybridization were as indicated in Methods. $\mathrm{O}, A_{260} ; 0,{ }^{3} \mathrm{H}$ hybridized.

associating component accounted for $90 \%$ of the total DNA and appeared to be kinetically homogeneous. (3) The $C_{0} t_{\frac{1}{2}}$ of the slowly reassociating component was 10 , which is about 2.5 times that of Escherichia coli sheared to equivalent fragment length (Ojha et al., 1977) and reassociated under comparable conditions (not shown in Fig. 2). Considering the genome size of $E$. coli to be $2 \cdot 8 \times 10^{9}$ daltons the molecular mass of $K$. marxianus DNA was calculated to be approximately $6.3 \times 10^{9}$ daltons.

\section{Separation of the rRNA cistrons}

The total cellular DNA was fractionated on a preparative neutral $\mathrm{CsCl}$ gradient and the individual fractions were hybridized with ${ }^{3} \mathrm{H}$-labelled rRNA from Allomyces arbuscula. The results indicated that most of the cistrons coding for rRNA banded at a slightly lower density than the main peak DNA where very little hybridization occurred (Fig. 3). 
The banding pattern of rRNA cistrons in $\mathrm{CsCl}$-actinomycin $\mathrm{D}$ and $\mathrm{Ag}^{+}-\mathrm{Cs}_{2} \mathrm{SO}_{4}$ gradients in cacodylate buffer $\mathrm{pH} 7 \cdot 0$ corresponded to the main peak DNA.

When bulk DNA was complexed with $\mathrm{Hg}^{2+}$ in borate buffer $\mathrm{pH} 9.2$ in $\mathrm{Cs}_{2} \mathrm{SO}_{4}$, centrifuged to equilibrium and individual fractions hybridized with ${ }^{3} \mathrm{H}$-labelled rRNA, the cistrons were found to band in the heavier regions of the main band (Fig. 4). However, the cistrons did not resolve into distinct satellites.

\section{DISCUSSION}

In $S$. cerevisiae and $S$. carlsbergensis, cistrons coding for rRNA appear as distinct satellites - the $\mathrm{Y}$ satellites - in analytical equilibrium density gradient centrifugations in $\mathrm{CsCl}, \mathrm{Hg}^{2+}-$ or $\mathrm{Ag}^{+}-\mathrm{Cs}_{2} \mathrm{SO}_{4}$ (Corneo et al., 1966; Cramer et al., 1972; De Kloet, 1970; Karijord \& Øyen, 1975). In contrast, we have not found any satellite with $K$. marxianus DNA under similar conditions of centrifugation.

Saturation hybridization experiments demonstrated that $2.2 \%$ of the DNA codes for $25+18 \mathrm{~S}$ rRNA in $K$. marxianus. This represents $1.4 \times 10^{8}$ daltons of coding sequences considering the genome size of $K$. marxianus to be $6.3 \times 10^{9}$ daltons (see below). The combined molecular mass of $25+18 \mathrm{~S}$ rRNA in yeast has been shown to be $2 \times 10^{6}$ daltons (Udem \& Warner, 1972). Therefore, $1.4 \times 10^{8}$ daltons of DNA should represent approximately 70 cistrons. This number is half of the 140 cistrons reported for $S$. cerevisiae (Schweizer et al., 1969). The control saturation hybridization values obtained with heterologous DNA from $S$. cerevisiae $(2.4 \%)$ and Neurospora crassa $(1 \%)$ correspond to the published results (De Kloet, 1970; Chattopadhyay et al., 1972) and attest to the validity of our method. The difference in chromosome number between $S$. cerevisiae (17) and $K$. marxianus (9) should not account for this difference, since Neurospora crassa with 7 chromosomes has 100 cistrons per nucleus (Chattopadhyay et al., 1972). Furthermore, an increase in the level of ploidy does not lead to any increase in the number of cistrons per nucleus in Physarum polycephalum (Hall et al., 1975).

The kinetics of reassociation indicated that repetitive sequences represent about $10 \%$ of the total DNA and that the $C_{0} t_{\frac{1}{2}}$ of the possible single copy sequence is 10 . This is about 2.5 times that of $E$. coli measured under comparable conditions. Physical measurements of $E$. coli have given a genome size of $2.8 \times 10^{9}$ daltons (Cairns, 1963), and so we calculate the genome size of $K$. marxianus to be approximately $6.3 \times 10^{9}$ daltons, assuming that the non-repeated portion represents approximately $90 \%$ of the total genome $\left(2.8 \times 10^{9}\right.$ $\times 2.5 \times 0.9$ ). This is in close agreement with the value published by Christiansen et al. (1971) for $K$. lactis.

$\mathrm{CsCl}$ gradient centrifugation results have shown that rDNA in $K$. marxianus is lighter than the main peak DNA, in contrast to $S$. cerevisiae where it is associated with a heavy satellite DNA (Schweizer et al., 1969). However, we found no evidence of a light satellite peak with $K$. marxianus. The specificity of actinomycin $\mathrm{D}$ binding to $\mathrm{G}+\mathrm{C}$ regions of the DNA has been used to separate the rRNA cistrons in higher organisms (Peacock et al., 1973). In our experiments with $K$. marxianus DNA the rRNA cistrons did not react differentially with actinomycin D and so did not appear as a satellite. However, separation was achieved with $\mathrm{Hg}^{2+}-\mathrm{Cs}_{2} \mathrm{SO}_{4}$ gradients where rRNA cistrons appeared in the heavier side of the gradient. The actinomycin $\mathrm{D}$ and $\mathrm{Hg}^{2+}$ binding experiments suggest that the rRNA cistrons in $K$. marxianus are A+T rich as in S. cerevisiae and A. arbuscula (Ojha \& Turian, 1977).

The authors are grateful to Professor G. Turian, Department of Plant Biology, University of Geneva, for laboratory facilities and constant encouragement, Dr J. P. Tessier, Department of Medical Biophysics, University of Claude Bernard, Lyon, for analytical centri- 
fugation, Miss A. Cattaneo for technical assistance and Mrs B. Duchoud for secretarial help.

\section{REFERENCES}

Bicknell, J. N. \& Douglas, H. E. (1970). Nucleic acid homologies among Saccharomyces. Journal of Bacteriology 101, 505-512.

BISHOP, J. O. (1972). DNA-RNA hybridization. In Karolinska Symposia on Research Methods in Reproductive Endocrinology. 5th Symposium: Gene Transcription in Reproductive Tissue, pp. 247-276. Edited by E. Dicfaluzy. Stockholm: Karolinska Institutet.

Britten, R. J. \& KoHne, D. E. (1968). Repeated sequences in DNA. Science 161, 529-540.

CaIrns, J. (1963). The chromosome of E. coli. Cold Spring Harbor Symposia on Quantitative Biology 28, 43-46.

CAMPBell, I. (1972). Numerical analysis of the genera Saccharomyces and Kluyveromyces. Journal of General Microbiology 73, 279-301.

Chattopadhyay, S. K., Kohne, D. E. \& Dutta, S. K. (1972). Ribosomal RNA genes of Neurospora crassa: isolation and characterization. Proceedings of the National Academy of Sciences of the United States of America 69, 3256-3259.

Christiansen, C., Leth BaK, A., Stendrup, A. \& Christiansen, G. (1971). Repetitive DNA in yeasts. Nature New Biology 231, 176-177.

Corneo, G., Moor, C., Sanadi, L., Grossman, I. \& Marmur, J. (1966). Mitochondrial DNA in yeast and some mammalian species. Science 151, 687-689.

Cramer, J. H., Bhargava, M. M. \& Halvorson, H. O. (1972). Isolation and characterization of rDNA of Saccharomyces cerevisiae. Journal of Molecular Biology 71, 11-20.

Cryer, D. R., Goldthwaite, C. D., Zinker, S., Lam, K. B., Storm, E., Hirschaerg, R., Blamire, J., Finkelstein, D. B. \& Marmur, J. (1973). Studies on nuclear and mitochondrial DNA of Saccharomyces cerevisiae. Cold Spring Harbor Symposia on Quantitative Biology 38, 17-30.

DE KLOET, S. R. (1970). The formation of RNA in yeast: hybridization of high molecular weight RNA species to yeast DNA. Archives of Biochemistry and Biophysics 136, 402-412.

DutTA, S. K. \& OJHA, M. (1972). Relatedness between major taxonomic groups of fungi based on the measurements of DNA nucleotide sequence homology. Molecular and General Genetics 114, 232-240.

Finkelstein, D. B., Blamire, J. \& Marmur, J. (1972). Location of ribosomal RNA cistrons in yeast. Nature New Biology 240, 279-281.

Galeotti, C. L. \& Willtams, K. L. (1978). Giemsa staining of mitotic chromosomes in Kluyveromyces lactis and Saccharomyces cerevisiae. Journal of General Microbiology 104, 337-341.

Hall, L. TuRnock, G. \& Cox, B. J. (1975). Ribosomal RNA genes in the amoebal and plasmodial forms of the slime mould Physarum polycephalum. European Journal of Biochemistry 51, 459-465.

KabaCK, D. B., Bhargava, M. M. \& Halvorson, H. O. (1973). Location and arrangement of genes coding for ribosomal RNA in Saccharomyces cerevisiae. Journal of Molecular Biology 79, 735 739.

KARIJORD, Ø. \& ØYEN, T. B. (1975). Study of haploid yeast with an unusually high rDNA content. II. Fractionation of the DNA in preparative $\mathrm{Ag}^{+}$$\mathrm{Cs}_{2} \mathrm{SO}_{4}$ density gradient. Biochimica et biophysica acta 383, 255-265.

KnitTel, M. D., Black, C. H., Sandine, W. A. \& FRASER, D. K. (1968). Use of normal probability paper in determining thermal melting values of deoxyribonucleic acid. Canadian Journal of Microbiology 14, 239-245.

OJHA, M. (1978). Characterization of spinach genome. Cytobiology 16, 185-198.

OJHA, M. \& TURIAN, G. (1977). Ribosomal RNA cistrons in Allomyces arbuscula. Biochimica et biophysica acta 478, 392-406.

Ojha, M., Turler, H. \& Turian, G. (1977). Characterization of Allomyces genome. Biochimica et biophysica acta 478, 377-391.

ØYEN, T. B. (1973). Chromosome I as a possible site for some rRNA cistrons in Saccharomyces cerevisiae. FEBS Letters 30, 53-56.

Peacock, W. J., Brutlag, D., Goldring, E., Appels, R., Hinton, C. W. \& Lindsley, D. L. (1973). The organization of highly repeated sequences in Drosophila melanogaster chromosome. Cold Spring Harbor Symposia on Quantitative Biology 38, 405-476.

RubiN, G. M. (1975). Preparation of RNA and ribosomes from yeast. Methods in Cell Biology 13, 45-64.

Schweizer, E., Mackechnie, E. \& Halvorson, H. O. (1969). The redundancy of ribosomal and transfer RNA genes in Saccharomyces cerevisiae. Journal of Molecular Biology 40, 261-277.

Tingle, M., Herman, A. \& Halvorson, H. O. (1968). Characterization and mapping of histidine genes in Saccharomyces lactis. Genetics 58, 361371.

Udem, S. A. \& WARNER, J. R. (1972). Ribosomal RNA synthesis in Saccharomyces cerevisiae. Journal of Molecular Biology 65, 227-242. 